\title{
Corporate Social Performance and Corporate Reputation: Two Interwoven Perspectives
}

\author{
Esther de Quevedo-Puente \\ Departamento de Economía y Administración de Empresas, \\ Facultad de CC.EE. y Empresariales, Burgos, Spain \\ Juan Manuel de la Fuente-Sabaté \\ Departamento de Economía y Administración de Empresas, \\ Facultad de CC.EE. y Empresariales, Burgos, Spain \\ Juan Bautista Delgado-García \\ Departamento de Economía y Administración de Empresas, \\ Facultad de CC.EE. y Empresariales, Burgos, Spain
}

Corporate Reputation Review, Vol. 10 , No. 1 , pp. $60-72$ (c) 2007 Palgrave Macmillan Ltd, $1363-3589 \$ 30.00$

\begin{abstract}
The conceptual closeness between corporate social performance (CSP) and corporate reputation (CR) and their convergence toward a common stakeholder framework has resulted in a concurrence of empirical analysis that has muddled the two lines of research. This paper tries to clear up the interrelation between CSP and CR. These concepts are linked by firm legitimation, a process that translates past performance into an expectation for the future. Legitimation transforms CSP, an objective flow variable, into $C R$, a perceptual stock variable.

Corporate Reputation Review (2007) 10, 60-72.

doi:10.1057/palgrave.crr.1550038
\end{abstract}

KEYWORDS: corporate reputation; corporate social performance; legitimation process; convergence; stakeholders

\section{INTRODUCTION}

Research on corporate social performance (CSP) and on corporate reputation (CR) has developed along parallel theoretical lines, with both concepts broadening theoretically to include all stakeholder relations. Moreover, in some cases empirical analyzes from both perspectives have employed the same variables, data and methods, reaching fundamentally identical results although with different interpretations. This convergence makes the contributions of the two approaches mutually enriching, but sometimes muddling.

This paper tries to point out differences and links that may clear up the interrelation between the two lines of research. The main difference is that reputation is largely informational and perceptual, whereas the concept of CSP attempts to account objectively for the firm's actions and attitudes. Another divergence arises from the different nature of the underlying theoretical frameworks: while the economic framework underlying research on reputation has an instrumental justification, the social framework underlying research on CSP emerges from a normative approach.

Both concepts are linked by a legitimation process that translates past actions (CSP) into 
expectations for the future (CR). CSP is the legitimate behavior of the firm with every stakeholder by the standards of the institutional context in each moment of time. Homogenous CSPs in successive periods in changing institutional contexts consolidate $\mathrm{CR}$, because economic agents translate the firm's past performance into expectations concerning future performance.

\section{THE SOCIOLOGICAL PERSPECTIVE: CSP}

CSP models have changed with the multiple redefinitions and reinterpretations of corporate responsibility in response to historical evolution, economic and political transformations, and even changes in the conceptual perspectives of the Theory of the Firm. An economic scenario governed by strict market mechanisms, which totally rules out any possibility of discretionary behavior by organizations, makes any debate on corporate responsibility banal, reducing that responsibility to the firm's continuity in satisfying the minimum expectations of its only stakeholder: the shareholder. Thus, Friedman (1962, 1970), from the suppositions of classical economics, argues that the firm's only social responsibility is to maximize its profits while respecting the basic rules of society that are reflected in law and in ethics. He maintains that the free-play market cannot resolve social problems, which must be left to government and legislation.

The emergence of large corporations at the beginning of the last century meant that the suppositions of classical economics, however, had to be rethought. An economy composed of many small firms, governed by the toing and froing of the market, was transformed into an economy organized around large corporations with highly concentrated economic and social power. The increasing complexity of corporations pushed management out of the hands of the classical shareholders into those of professional managers. The separation of ownership and control
(Berle and Means, 1932) meant the introduction of a new agent, the management, endowed with great discretion, and forced economists to recognize managers' interests and claims in the firm (Baumol, 1965; Marris, 1963; Williamson, 1963).

After the conquest of power by the big corporations during the first decades of the 20th century, the 1960s and 1970s were years of social opposition. Society became aware of and concerned about respect for the environment, the treatment of workers, product safety, etc. There was thus an attempt to demonstrate the existence of other stakeholders with their own claims on the firm. These developments were backed by the transition, in the political sphere, from a free market economy to a mixed economy, with governments that played a part in the business world. Under these circumstances, managers were forced to broaden their concept of the firm and recognize the claims of every stakeholder in the firm, in order to avoid social reaction and maintain a degree of freedom out of reach of legislative interference.

In an attempt to enlarge the definition of corporate responsibility and adapt it to the new social environment, Carroll (1979) developed a model in which discretionary social responsibilities were added to economic, legal and ethical ones. The classical roots of his model, however, were apparent, since it still pointed to economic responsibility as the main obligation of the firm. He recognized the political and social power assumed by modern corporations, but continued to interpret it restrictively. From a theoretical point of view, this is a very attractive model, because of its intuitive formulation. It has, however, not really been useful as a framework for empirical research (Wood and Jones, 1995), since no significant relations have been proven among its various components (Aupperle et al., 1985; Pinkston and Carroll, 1993).

Finally, the transformations in the economic environment extended to theoretical 
proposals. A new, more realistic paradigm emerged, describing the firm as a set of relations with different stakeholders: employees, suppliers, clients, shareholders and society (Freeman, 1984; Hill and Jones, 1992; Clarkson, 1995). This broadening of the concept of the firm has required us to rethink the objectives and responsibilities of organizations. A review of the literature shows that there has been a progressive introduction of the stakeholder approach into models proposed from the classical tradition, parallel to the development of this perspective within the Theory of the Firm (Wartick and Cochran, 1985; Wood, 1991; Wood and Jones, 1995; Clarkson, 1995). Hence the interest in models of CSP has moved on, from analyzing the convenience for the shareholder of the firm's philanthropic activities (Carroll, 1979) to analyzing the firm's behavior in a set of relations with clients, suppliers, shareholders, employees, managers, the community and the environment, all considered as stakeholders (Wood and Jones, 1995; Waddock and Graves, 1997a; Carroll, 2000; Rowley and Berman, 2000; Jones, 1980; Clarkson, 1995).

This definition of CSP has extended the responsibility of the firm's management, which shifts from being a mere agent of shareholders (Friedman, 1962, 1970) to being the guarantor of every stakeholder's satisfaction (Wood and Jones, 1995; Waddock and Graves, 1997a; Carroll, 2000; Rowley and Berman, 2000; Jones, 1980; Clarkson, 1995). Thus a new area of research arises that attempts to relate financial performance to the managers' orientation towards stakeholders' interests (Clarkson, 1995; Greenley and Foxall, 1997). 'Performance' goes beyond the reward of shareholders and includes the distribution of value to all stakeholders (Clarkson, 1995; Waddock and Graves, 1997a).

There is an ample consensus about the content of CSP as a comprehensive assessment of the firm's performance with every stakeholder group (Carroll, 2000; Rowley and Berman, 2000; Jones, 1980). Universal CSP measures, however, are not desirable, because measuring CSP is contingent on variables such as time, culture, industry and context (Rowley and Berman, 2000; Griffin, 2000).

\section{THE ECONOMIC PERSPECTIVE: THE INFORMATION CONTENT OF CR}

From the economic perspective, reputation has been studied for its information content. In situations of information asymmetry, the informed agent can profit at the expense of uninformed agents. The result of these relations, however, may give information about the behavior of the informed agent. After several iterations, others' observation of this result will generate a reputation, which will signal the most likely behavior of the informed individual in the future. The process of constructing a reputation, and its subsequent use as a signal to forecast the potential behavior of agents, has been widely analyzed within Information Theory and Games Theory. Much of the work was focused on predatory practices by firms facing the entry of new competitors into the sector (Kreps and Wilson, 1982; Milgrom and Roberts, 1982) and on reputation for the quality of products (Nelson, 1970; Milgrom and Roberts, 1986) and services (Wilson, 1983; De Angelo, 1981; Eichenseher and Shields, 1985; Dranove, 1983; Rogerson, 1983; Beatty and Ritter, 1986).

The prevailing paradigm in the Theory of the Firm was still that proposed by Industrial Organization (Bain, 1959; Mason, 1949), which situated the strategic nucleus of the firm in its environment. Although the existence of intangible assets had already been noted, they were somewhat artificially materialized as barriers to mobility. The absence of an integrative model of the firm affected the concept of reputation, which took on an impoverished, partial and fragmented form. From this perspective, corporate behavior was analyzed in a determinist way. 
In its search for precise and 'desirable' responses from different economic agents, the firm repeated the conduct that provoked this 'desirable' behavior - say, aggressive responses that had inhibited a new competitor (Milgrom and Roberts, 1982), or the sale of a quality product that had induced consumers to repeat their purchases (Rogerson, 1983). These repeated actions of the firm consolidated a reputation that led each agent to select, among its options, which best suited the firm's interests.

The decline in analyses of Industrial Organization, from both academic and managerial perspectives, enabled a new theoretical framework to appear that has allowed us to study the inside of the firm: the stakeholder approach (Jensen and Meckling, 1976; Hill and Jones, 1992; Rajan and Zingales, 1998). This perspective describes the firm as a contractual nexus among its different stakeholders (Jensen and Meckling, 1976; Rajan and Zingales, 1998). This new concept of the firm has enabled the development of the concept of CR, a new and more integrative definition of reputation, that takes into account the relation of the firm with every stakeholder.

The literature taking the stakeholder approach has provided several definitions of $\mathrm{CR}$. Wartick (1992: 34) defined it as 'the aggregation of a single stakeholder's perceptions of how well organizational responses are meeting the demands and expectations of many organizational stakeholders'. Following similar arguments, Fombrun (2002: 9) proposed that 'CR is the collective representation of a company's past actions and future prospects that describes how key resource providers interpret a company's initiatives and assess its ability to deliver valued outcomes'. Waddock (2000: 323) proposed that reputation 'is the organization's perceived capacity to meet their stakeholders expectations'.

Among these definitions two key points can be stressed (Brown and Logsdon, 1997). First, this construct has a perceptual nature.
Some individual, group or larger human collective gathers and processes information about a firm's past actions and draws conclusions about its future prospects. Second, CR is a net or aggregate perception by every stakeholder, not just one or two.

$\mathrm{CR}$ is not only an information signal (Akerlof, 1970) but also a guarantor of contracts (Cornell and Shapiro, 1987), since the firm that does not satisfy the expectations of its stakeholders will lose the capital accumulated in this asset. Resource holders will be attracted to the well-reputed firm not only because they know what it is likely to do purely on past form, but also because they know that the expectations generated by CR are self-fulfilling, since the firm that does not satisfy expectation generated by its reputation will lose it. Thus, the well-reputed firm occupies a privileged position in markets, allowing it to attract better resources on more favorable terms.

\section{THE CONVERGENCE OF THE EMPIRICAL RESEARCH}

The research on CSP and that on CR have evolved in parallel: The classical essence has become watered down, and both perspectives have converged towards a stakeholder framework that gives consistency to the contributions made by both. It is, however, important to reemphasize that CSP has a descriptive nature while CR has a perceptual nature. CSP describes, from an 'objective' point of view, the firm's performance with respect to stakeholders, while CR is the sum of stakeholders' perceptions of the firm's capacity to fulfill their interests. In this sense, it seems proper to use objective databases to measure CSP and perceptual surveys to measure CR. In this section, we describe the development of the empirical research on CSP and on CR in order to highlight the coincidences of data and methods between the two lines of research.

The measurement of social responsibility of the firm, or, more recently, 'CSP', has been 
an object of debate and has evolved since the 1960s. In the first papers, which used a narrower concept of corporate responsibility, authors tried to approach it through a firm's action in some key social area, such as pollution control (Bragdon and Marlin, 1972; Folger and Nutt, 1975; Spicer, 1975), contributions to the community in the form of donations and philanthropic work (Levy and Shatto, 1980), the integration of women and minority groups within the company (Kedia and Kuntz, 1981), or a mixture of these (Kedia and Kuntz, 1981). The information sources for these papers were mainly data issued by the Council on Economic Priorities or firms' annual reports (Bowman and Haire, 1975). Boresford $(1973,1975,1976)$ elaborated a series of data using the annual reports of firms that were then used by other authors as a starting point for their analyses (Abbott and Monsen, 1979; Anderson and Frankle, 1980; Ingram, 1978; Preston, 1978). These works referred only to isolated aspects of social responsibility and were not all valid for every industry.

A broader valuation was provided by Moskowitz (1972, 1975), who, by analyzing the contents of several sources, such as the regular business press, the annual reports of organizations, publications that watched over various social matters and the reports issued by the firms themselves, was able to evaluate the satisfaction of certain legitimate claims of each of the stakeholders - clients, employees and society - and to classify a number of firms as excellent, honorable or awful in their social behavior. The topics Moskowitz considered were pollution control, equal employment opportunities, minority and female representation on the Board of Directors, support of minority enterprises, responsible or irresponsible advertising, charitable contributions, community relations, product quality, plant safety, illegal politicking, disclosure of information, employee benefits, respect for privacy, support for cultural programs, responsiveness to client complaints and fair dealing with customers (Moskowitz, 1975). ${ }^{1}$ This index attempted to reflect firms' actual behavior and it has been used only for research into the firm's social responsibility; however, it has been paradoxically accused of rather being a measure of reputation (Ullman, 1985).

One evaluation that did resort to perceptual sources was the index made by the National Association of Concerned Business Students (1972), which surveyed 300 students and asked them to evaluate the social responsibility of some of the firms included in the Fortune 500 (Alexander y Buchholz, 1978). Obviously, although this index has been used only in researches on corporate social responsibility, its perceptual nature has raised criticisms of being a measure of reputation and, therefore, not really suitable as an indicator of corporate behavior (Ullman, 1985).

During the 1980s, and even the beginning of the 1980s, research using event methodology appeared within the tradition of research on CSP (McWilliams et al., 1999) to evaluate the impact of responsible or irresponsible actions by the firm on short-term financial performance. The studies dealt with several but again narrow issues ranging from development of affirmative action programs (Wright et al., 1995), disinvestments in South Africa in the age of apartheid (Meznar et al., 1994; Teoh et al., 1999; Posnikoff, 1997; Wright and Ferris, 1997), plant closures (Clinebell and Clinebell, 1994) and lawsuits over discrimination (Wright et al., 1995) to the announcement of withdrawal of a product (Davidson and Worrell, 1992) or failure to comply with the law (Frooman, 1997). McWilliams et al. (1999), surveying five papers dealing with a single aspect of CSP, obtained mutually inconsistent results and highlighted the lack of robustness of these results. From a more theoretical perspective, McWilliams and Siegel (1997) argue that event methodology does not seem appropriate for research on CSP, since this calls for 
consideration of the impact of managerial decisions on all the stakeholders and not only on shareholders' interests.

During the 1970s and the beginning of the 1980 s, research on reputation was focused on analyzing its information content using Information Theory and Games Theory (Weigelt and Camerer, 1988). This literature, still markedly influenced by Industrial Organization, focused on firms' reputation for predatory practices when faced with the threat of new competitors in the sector (Kreps and Wilson, 1982; Milgrom and Roberts, 1982) and on the quality of products (Klein and Leffler, 1981; Shapiro, 1983;Allen, 1984) and services (Wilson, 1983; De Angelo, 1981; Rogerson, 1983; Beatty and Ritter, 1986). These papers were markedly normative, while their empirical analysis was formalist, with a broad mathematical modelling.

At the beginning of the 1980s, Fortune released Most Admired American Companies ranking. Executives, directors and market analysts are surveyed to rate large corporation on the following eight qualitative attributes: quality of management, quality of products or services, value as long-term investment, innovativeness, soundness of financial position, ability to attract, develop, and keep talented people, responsibility to the community and environment, and wise use of corporate assets. This rating signaled the incipient convergence between the two perspectives. Corporate social responsibility began to be measured through the attribute 'responsibility to the community and environment' (McGuire et al., 1988; Cottrill and Faust, 1991). This approach is not without criticisms. Wood (1995: 198) questions the validity of the ranking published in Fortune as a measure of CSP, because 'it is itself a fatal blow to using the reputational measure in any objective sense'. At the same time, researchers in the economic tradition began to use items from the Fortune survey to analyze specific aspects of firm reputation, as in the work of McGuire et al. (1990) on reputation for management quality; others (Brown, 1997, 1998) also studied reputation with respect to social behavior; and they even used the attribute 'responsibility to the community and environment' employed by the sociological perspective (McGuire et al., 1988). The drawing together of the two perspectives was such that some sociologically based works, such as that of McGuire et al. (1988), incorporated economic justifications ${ }^{2}$ for the link between the social responsibility of the firm and financial performance.

The development of the Theory of the Firm (Jensen and Meckling, 1976; Freeman, 1984; Clarkson, 1995; Hill and Jones, 1992; Rajan and Zingales, 1998) has broadened the description of the firm to include every stakeholder. This has translated into a widening of both concepts: reputation to CR, and corporate social responsibility to include the evaluation of the firm's relations with all its stakeholders (Wood and Jones, 1995; Waddock, 1996). The theoretical enlargement of the two perspectives, of course, has implied a redesigning of empirical analyses, and papers have begun to appear that take into account the eight factors evaluated by Fortune magazine, both in the economic literature (Fombrun and Shanley, 1990; Riahi-Belkaoui and Pavlik, 1991; Hammond and Slocum, 1996; Srivastava et al., 1997; Deephouse, 1997; Roberts and Dowling, 1997; Cordeiro and Sambharya, 1997; Black et al., 2000; Vergin and Qoronfleh, 1998) and in the sociological literature (Little and Little, 2000; Jones et al., 2000).

Another alternative measurement that contains evaluations of the behavior of firms toward their principal stakeholders (Graves and Waddock, 1994) is provided by Kinder, Lydenberg and Domini \& Co. (KLD). Although the KLD evaluations have been the data most widely used in research into CSP, Sharfman (1996), Waddock and Graves (1997b) and Brown and Perry (1994) show that they are related to the reputational rankings published by Fortune. Sharfman 
shows significant although not unbelievably high correlations, maintained within an interval of $0.3-0.5$ depending on the composition of the items and of the sample. Using regression analysis, Waddock and Graves provide evidence that five of the KLD categories explain more than half the variability in the Fortune evaluations. Brown and Perry, applying correlation and regression analyses, conclude strong association between four halo removed items ${ }^{3}$ of the Fortune and KLD evaluations. These results seem to show that reputation has at least some basis in objective reality that makes CSP and CR have a close interrelation, despite their differences.

In short, this evolution has taken us from a concept of CSP based on discretionary or philanthropic behavior (Carroll, 1979, 1996) to a wider definition that incorporates all of the relations of the firm with its stakeholders (Wood and Jones, 1995; Waddock, 1996; Waddock and Graves, 1997a). At the same time, from the economic tradition, the content of reputation has also been broadened, going from partial definitions, such as the inclination towards certain types of conduct or the quality of behavior towards a specific stakeholder (Nelson, 1970; Milgrom and Roberts, 1986; Wilson, 1983; De Angelo, 1981; Eichenseher and Shields, 1985; Dranove, 1983; Rogerson, 1983; Beatty and Ritter, 1986), to a CR for the fulfillment of every stakeholder's expectations (Wartick, 1992; Fombrun, 2002; Waddock, 2000; Sandberg, 2002). Moreover, this theoretical concurrence has been accompanied by an empirical convergence that even leads researchers to use the same databases, although with nominally distinct interpretations of results. Finally, crossreferences have appeared more and more frequently between the two traditions (Hammond and Slocum, 1996; Riahi-Belkaoui and Pavlik, 1991). This parallel development has brought about confusion. In the next section, we try to clear up the link and the differences between CSP and CR.

\section{THE LEGITIMATION PROCESS: THE THREAD LEADING FROM CSP TO CR}

As we anticipated in the previous section, the evolution of the research tradition suggests CSP as a comprehensive assessment of firm's performance with every stakeholders group (Carroll, 2000; Rowley and Berman, 2000; Jones, 1980). The measure of CSP, however, is not universal, but contingent on variables such as time, culture, industry and context (Rowley and Berman, 2000; Griffin, 2000). In essence, CSP describes the legitimacy of the firm's behavior towards its stakeholders by the standards of its institutional context at a particular moment in time. A firm is understood to behave legitimately when its actions are congruent with society's expectations (Suchman, 1995). Those expectations are determined by institutional context: norms, values, beliefs and social definitions. Therefore, institutional context is the criterion for evaluating the legitimacy of the firm's attitudes towards stakeholders and thus its social performance.

Proposition 1: CSP describes the degree of legitimacy of the firm's behavior by the standards of its institutional context.

Because the institutional context changes continuously, CSP has to be redefined at each moment in time. Companies face growing complexity in the institutional context in which they interact. These transformations affect the relations of the firm with its stakeholders. Through time institutional context has begun to take into account previously ignored issues such as pollution, solidarity behaviors, etc, and these changes influence how the stakeholders think and what they expect in their relations with firms. In fact, the definition of Corporate Social Responsibility and therefore of a good social performer has shifted over time. Firms are in a continual process of legitimation, 
trying to evolve in step with the changes in social norms, beliefs, values and definitions (Carroll, 1996). A firm whose performance on a particular issue leads or lags the evolution of societal expectations will lose its organizational legitimacy (Zyglidopoulos, 2003); one that stays in step will experience a constant acceptance by its stakeholders and by society in general.

The firm's audiences - economic agents - will observe that it consistently meets social expectations in its relations with its stakeholders, and will translate past firm performance into expectations about future performance. That is, when a firm is a good social performer, adapting to different institutional contexts over time, it consolidates its CR stock. In contrast, a firm that lags behind the evolution of the institutional context is not a good social performer, and this will reduce its CR.

In this sense, CR is an asset of social construction (Fombrun and Rindova, 1994), created and maintained through a process of legitimation (Rao, 1994) that involves a continuous succession of specific evaluations of the firm's actions by the standards of the institutional context at any given moment. After long observation, the accumulation of homogenous evaluations of firm's social performance in successive periods generates a CR (Logsdon and Wood, 2002), because stakeholders translate past firm's social performance into expectative of future behavior (Weizsacker, 1980; cited by Williamson, 1985). We can therefore deduce that the parallelism between the research on CSP and that on CR is rooted in the interaction between the two concepts through the process of legitimation.

Proposition 2: CR is consolidated through legitimation as the accumulation of similar social performances by the firm over time.
CSP is an objective variable, because it describes the behavior of the firm with every stakeholder in a given institutional context at a moment of time. CSP is also a flow variable, because a firm may change its social performance at every moment of time. A good social performer may fail to adapt to changes in the institutional context and become a poor social performer; a poor social performer can change its behaviors, adapting them to the institutional context, and become a good social performer.

Proposition 3: CSP is an objective flow variable.

In contrast, $\mathrm{CR}$ is a perceptual variable, because $\mathrm{CR}$ is the aggregation of the stakeholders' expectations about the future behavior of the firm. Furthermore, CR is a stock variable, because its value at a given moment of time is not independent of its value in the past. Indeed, CR depends on the firm's social performance in the past and the present (Schultz et al., 2001), because the firm's fulfillment of stakeholders interest in the past, generates expectative of fulfillment in the future.

Proposition 4: $C R$ is a perceptual stock variable.

So CSP relates to CR the same way publicity investment relates to image. Investment in publicity may change every year, and its accumulative effect makes up image. Image does not change every year, but its value is determined by its past value and publicity investment at present. Despite essential differences - the objective and precise nature of CSP compared with the subjective and intertemporal nature of reputation - their mutual link with legitimation means that there are many points in common in the research (Figure 1).

\section{CONCLUSION}

The parallel evolution of CR and CSP concepts has developed in a rapprochement of 


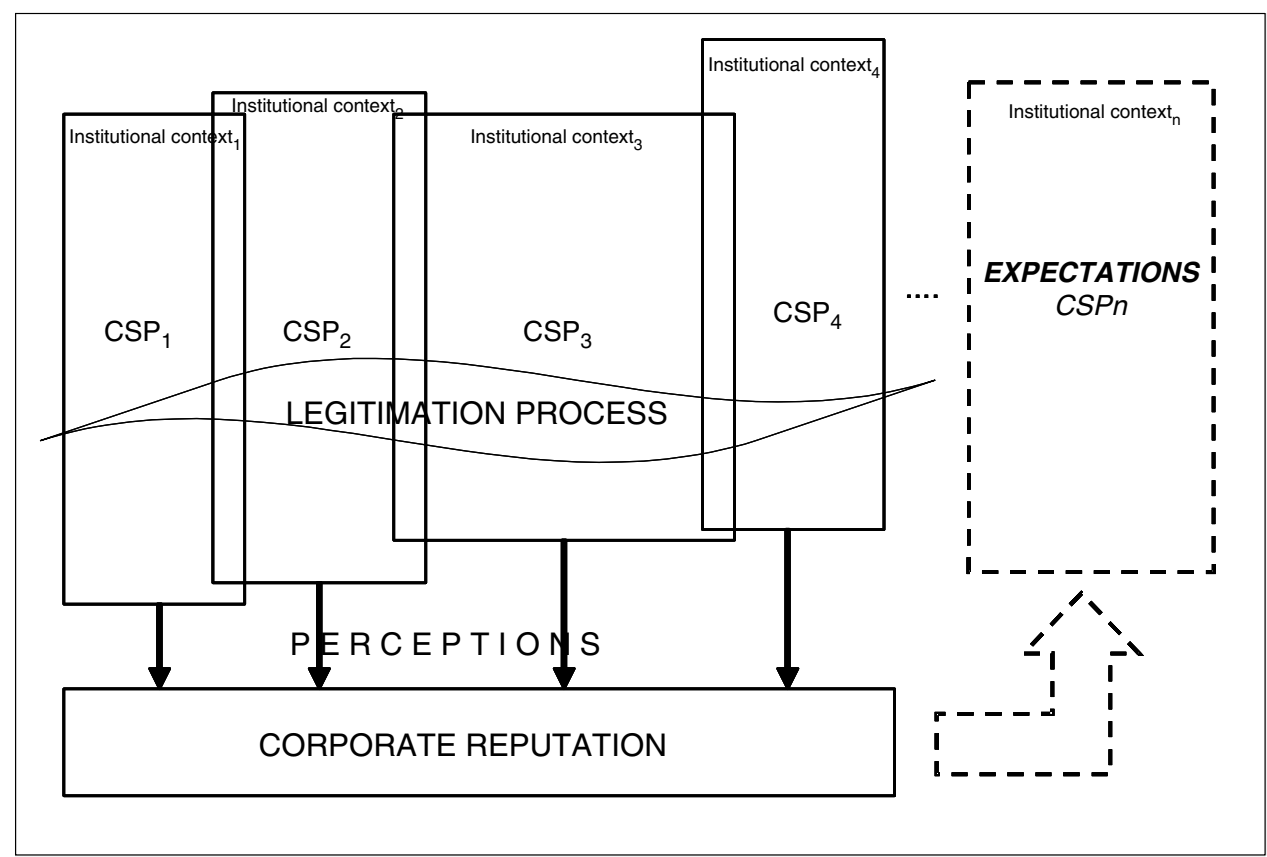

Figure 1: The relation between corporate social performance (CSP) and corporate reputation

methodologies between research on CSP and research on CR. In fact, analyses of both lines of research have been done with the same variables, data and methodologies, hence reaching fundamentally identical results, although their interpretations have been different. This convergence makes the contributions of the two approaches mutually enriching, but sometimes muddling. The convergence between both lines of research is not but a consequence of their closeness. $\mathrm{CR}$ and CSP include firm's relations with every stakeholder in their definition. CSP, however, is an objective variable whereas CR is a perceptual variable. That is, CSP is a comprehensive assessment of firm's fulfilment of stakeholders expectations, whereas $\mathrm{CR}$ is the firm's perceived capacity to meet stakeholders expectations. In essence, CSP describes how the firm delivers value at a moment of time among stakeholders and $\mathrm{CR}$ is the perception of how the firm is going to deliver value in the future. One is objective, the other perceptual; one describes the past, the other predicts the future.
What links them is the process of legitimation. A good firm performance over time consolidates CR because past fulfilment of stakeholders expectations generates an expectation of future fulfilment. To generate this expectation, the firm seeks legitimation by adapting its behaviors to the institutional context at each moment of time.

\section{Notes}

1 Many studies have been done using the data given by Moskowitz, such as those of Sturdivant and Ginter (1977) and Vance (1975), which analyze the link between corporate social responsibility and financial performance.

2 In fact, these authors argue that stakeholders in firms that behave responsibly have confidence in the satisfaction of their implicit rights and therefore will not demand the explicit formalization of these rights, a formalization that would carry costs and thus would ultimately harm corporate financial performance.

3 Fortune's data after applying Brown and Perry's method to remove financial performance bias of executives and industry analyst in their qualitative ratings on firms. 
Brown, B. (1998) 'Do stock market investors reward companies with reputations for social performance?' Corporate Reputation Review, 1, 271-280.

Brown, B. and Logsdon, J.M. (1997) 'Factors influencing Fortune's corporate reputation for "Community and Environmental Responsibility", in Weber J. and Rehbein K. (eds.), Proceedings of the 8th Annual Meeting of the International Association for Business and Society, pp. 184-189.

Brown, B. and Perry, S. (1994) 'Removing the financial performance Halo from Fortune's "Most Admired Companies", Academy of Management Journal, 37(5), 1347-1359.

Carroll, A.B. (1979) 'A three-dimensional conceptual model of corporate social performance', Academy of Management Review, 4, 497-506.

Carroll, A.B. (1996) Business and Society: Ethics and Stakeholder Management, South-western College Publishing, Cincinnati.

Carroll, A.B. (2000) 'A commentary and an overview of key questions on corporate social performance measurement', Business and Society, 39(4), 466-478.

Clarkson, M.B.E. (1995) 'A stakeholder framework for analysing and evaluating corporate social performance', Academy of Management Review, 20, 92-117.

Clinebell, S.K. and Clinebell, J.M. (1994) 'The effect of advanced notice of plant closings on firm value', Journal of Management, 20, 553-564.

Cordeiro, J.J. and Sambharya, R.B. (1997) 'Do corporate reputations influence security analyst earnings forecast? An empirical study', Corporate Reputation Review, 1, 94-97.

Cornell, B. and Shapiro, A.C. (1987) 'Corporate stakeholders and corporate finance', Financial Management, 16, 5-14.

Cottrill, M. and Faust, B. (1991) 'Corporate social performance and foreign sales exposure', In Mahon, J. (ed.) Proceedings of the 2nd Annual Meeting of the International Association for Business and Society, pp. 354-360.

Davidson, W. and Worrell, D. (1992) 'The effect of announcements on shareholder wealth', Strategic Management Journal, 13, 553-564.

De Angelo, L. (1981) 'Auditor size and auditor quality', Journal of Accounting and Economics, 3, 183-200.

Deephouse, D.L. (1997) 'The effect of financial and media reputations on performance', Corporate Reputation Review, 1, 68-71.

Dranove, D. (1983) An Economic Model of the Physician-patient Relationship, Ph.D. Thesis, Graduate School of Business, Stanford University.

Eichenseher, J. and Shields, D. (1985) 'Corporate director liability and monitoring preferences', Journal of Accounting and Public Policy, 4, 13-31. 
Folger, H.R. and Nutt, F. (1975) 'A note on social responsibility and stock valuation', Academy of Management Journal, 18, 155-159.

Fombrun, C. (2002) Corporate Reputation: Research and Practice, Presented at Conversazione. April, Santa Fe, NM.

Fombrun, C. and Rindova, V. (1994) Reputations as Cognitive Constructions of Competitive Advantage, Conference on the Cognitive Construction of Industries, Chicago, IL.

Fombrun, C. and Shanley, M. (1990) 'What's in a name? Reputation building and corporate strategy', Academy of Management Journal, 33, 233-258.

Freeman, R.E. (1984) Strategic Management: A Stakeholder Approach, Pitman, Boston.

Friedman, M. (1962) Capitalism and Freedom, University of Chicago Press, Chicago.

Friedman, M. (1970) 'The social responsibility of business is to increase its profits', New York Times Magazine, September 13, p. 33.

Frooman, J. (1997) 'Socially irresponsible and illegal behavior and shareholder wealth. A meta-analysis of event studies', Business and Society, 36, 221-249.

Graves, S. and Waddock, S. (1994) 'Institutional investors and corporate social performance', Academy of Management Journal, 37, 1035-1046.

Greenley, G.E. and Foxall, G.R. (1997) ‘Multiple stakeholder orientation in UK companies and the implications for company performance', Journal of Management Studies, 34, 259-284.

Griffin, J.J. (2000) 'Corporate social performance: Research directions for the 21st century', Business and Society, 39(4), 479-491.

Hammond, S.A. and Slocum, J.W. (1996) 'The impact of prior firm financial performance on subsequent corporate reputation', Journal of Business Ethics, 15, 159-165.

Hill, C.W.L. and Jones, T.M. (1992) 'Stakeholder-agency theory', Journal of Management Studies, 29(2), 131-154.

Ingram, R.W. (1978) 'An investigation of the information content of certain social responsibility disclosures', Journal of Accounting Research, 16, 270-285.

Jensen, M.C. and Meckling, W. (1976) 'Theory of the firm: Managerial behavior, agency cost and ownership structure', Journal of Financial Economics, 3(4), 305-360.

Jones, G., Jones, B. and Little, P. (2000) 'Reputation as a reservoir: Buffering against loss in times of economic crisis', Corporate Reputation Review, 3, 21-29.

Jones, T.M. (1980) 'Corporate social responsibility revisited, redefined', California Management Review, 22(3), 59-67.
Kedia, B.L. and Kuntz, E.C. (1981) 'The context of social performance: An empirical study of Texas Banks', in L. E. Preston (ed.), Research in Corporate Social Performance and Policy, JAI Press, Greenwich, Connecticut, pp. 133-154.

Klein, B. and Leffler, K. (1981) 'The role of market forces in assuring contractual performance', Journal of Political Economy, 89, 615-641.

Kreps, D. and Wilson, R. (1982) 'Reputation and imperfect information', Journal of Economic Theory, 27, 253-279.

Levy, K. and Shatto, G.M. (1980) 'Social responsibility in large electric utility firms: The case for Philanthropy', Research in Corporate Social Performance and Policy, 2, 237-249.

Little, P.L. and Little, B.L. (2000) 'Do perceptions of corporate social responsibility contribute to explaining differences in corporate price-earnings ratios?' Corporate Reputation Review, 3, 137-142.

Logsdon, J.M. and Wood, D.J. (2002) 'Reputation as an emerging construct in the business and society field. An introduction', Business and Society, 41(4), 365-370.

Marris, R. (1963) 'A model of the "Managerial" enterprise', Quarterly Journal of Economics, 2(May), 185-210.

Mason, E. (1949) 'The current state of the monopoly problem in the US', Harvard Law Review, 62(8), 1265-1285.

McGuire, J.B., Schneeweis, T. and Branch, B. (1990) 'Perceptions of firm quality: A cause or result of firm performance', Journal of Management, 16, 167-180.

McGuire, J.B., Sundgren, A. and Schneeweis, T. (1988) 'Corporate social responsibility and firm financial performance', Academy of Management Journal, 31, 854-872.

McWilliams, A. and Siegel, D. (1997) 'Event studies in management research: Theoretical and empirical issues', Academy of Management Journal, 40, 626-657.

McWilliams, A., Siegel, D. and Teoh, S.H. (1999) 'Issues in the use of the event study methodology: A critical analysis of corporate social responsibility studies', Organizational Research Methods, 2, 350-372.

Meznar, M., Nigh, D. and Kwok, C. (1994) 'Effect of announcements of withdrawal from South Africa on stockholder wealth', Academy of Management Journal, 37, 1636-1648.

Milgrom, P. and Roberts, J. (1982) 'Predation, reputation and entry deterrence', Journal of Economic Theory, 27, 280-312.

Milgrom, P. and Roberts, J. (1986) 'Price and advertising signals of product quality', Journal of Political Economy, 94, 796-821.

Moskowitz, M. (1972) 'Choosing socially responsible stocks', Business and Society Review, 1, 71-75. 
Moskowitz, M. (1975) 'Profiles in corporate responsibility', Business and Society Review, 13, 29-42.

National Association of Concerned Business Students (1972) 'How business school students rate corporations', Business and Society Review, 2, 20-21.

Nelson, P. (1970) 'Information and consumer behavior', Journal of Political Economy, 78, 311-329.

Pinkston, T.S. and Carroll,A.B. (1993) 'An investigation of the relationship between organizational size and corporate social performance', In Pasquero J. and Collins D. (eds.) Proceedings of the 4th Annual Meeting of the International Association for Business and Society, pp. 109-114.

Posnikoff, J.F. (1997) 'Disinvestment from South Africa: They did well by doing good', Contemporary Economic Policy, 15(1), 76-86.

Preston, L.E. (1978) 'Analyzing corporate social performance: Methods and results', Journal of Contemporary Business, 7(1), 135-149.

Rajan, R.G. and Zingales, L. (1998) 'The Governance of the New Enterprise', University of Chicago, http://gsblgz.uchicago.edu.

Rao, H. (1994) 'The social construction of reputation: Certification contest, legitimation, and survival of organizations in the American automobile industry: 1895-1912', Strategic Management Journal, 15, 2944.

Riahi-Belkaoui, A. and Pavlik, E. (1991) 'Asset management performance and reputation building for large US firms', British Journal of Management, 2, 231-238.

Roberts, P.W. and Dowling, G.R. (1997) 'The value of a firm's corporate reputation: How reputation helps attain and sustain superior profitability', Corporate Reputation Review, 1, 72-75.

Rogerson, W. (1983) 'Reputation and product quality', Bell Journal of Economics, 14, 508-516.

Rowley, T. and Berman, S. (2000) 'A brand new brand of corporate social performance', Business and Society, 39(4), 397-418.

Sandberg, K.D 2002 'Kicking the tires of corporate reputation', Harvard Management Comunication Letter, 5(1), 5-6.

Schultz, M., Mouritsen, J. and Grabielsen, G. (2001) 'Sticky reputation: Analyzing a ranking system', Corporate Reputation Review, 22, 24-41.

Shapiro, C. (1983) 'Premiums for high quality products as returns to reputations', Quarterly Journal of Economics, 98(November), 659-679.

Sharfman, M. (1996) 'The construct validity of the Kinder, Lydenberg and Domini social performance ratings data', Journal of Business Ethics, 15, 287-296.

Spicer, B.H. (1975) 'Investors, corporate social performance and information disclosure: An empirical study', Accounting Review, 53, 94-111.
Srivastava, R.K., McInish, T.H., Wood, R.A. and Capraro, A.J. (1997) 'The value of corporate reputation: Evidence from equity markets', Corporate Reputation Review, 1(1 and 2), 62-67.

Sturdivant, F.D. and Ginter, J.L. (1977) 'Corporate social responsiveness: Management attitudes and economic performance', California Management Review, 19(3), 30-39.

Suchman, M. (1995) 'Managing legitimacy: Strategic and institutional approaches', Academy of Management Review, 20, 571-610.

Teoh, S.H., Welch, I. and Wazzan, C.P. (1999) 'The effect of socially activist investment policies on the financial markets: Evidence from the South African boycott', Journal of Business, 72, 35-89.

Ullman, A. (1985) 'Data in search of a theory: A critical examination of the relationship among social performance, social disclosure and economic performance', Academy of Management Review, 19, 450477.

Vance, S.C. (1975) 'Are socially responsible corporations good investment risks?' Management Review, 64(8), 19-24.

Vergin, R.C. and Qoronfleh, M.W. (1998) 'Corporate reputation and the stock market', Business Horizons, 41(1), 19-26.

Waddock, S.A. (1996) 'Strategy, structure, and social performance: Implications of the W-form enterprise', Business and the Contemporary World, 1, 43-51.

Waddock, S. (2000) 'The multiple bottom lines of corporate citizenship: Social investing, reputation, and responsibility audits', Business and Society Review, 105, 323-345.

Waddock, S.A. and Graves, S.B. (1997a) 'The corporate social performance-financial performance link', Strategic Management Journal, 18, 303-319.

Waddock, S.A. and Graves, S.B. (1997b) 'Quality of management and quality of stakeholder relations: Are they synonymous?' Business and Society, 36, 250-280.

Wartick, S.L. (1992) 'The relationship between intense media exposure and change in corporate reputation', Business and Society, 31, 33-42.

Wartick, S.L. and Cochran, P.L. (1985) 'The evolution of the corporate social performance model', Academy of Management Review, 10, 758-769.

Weigelt, K. and Camerer, C. (1988) 'Reputation and corporate strategy: A recent theory and applications', Strategic Management Journal, 9, 443-454.

Von Weizsacker, C.C. (1980) Barriers to Entry, Springer-Verlag, New York.

Williamson, O.E. (1963) 'Managerial discretion and business behavior', American Economic Review, 53(5), 1032-1057. 
Williamson, O.E. (1985) The Economics Institutions of Capitalism: Firms, Markets, Relational Contracting, The Free Press, New York.

Wilson, R. (1983) 'Auditing: Perspectives from multiperson decision theory', Accounting Review, 58, 305-318.

Wood, D.J. (1991) 'Corporate social performance revisited', Academy of Management Review, 16, 691-718.

Wood, D.J. (1995) 'Introduction. The Fortune database as a CSP measure', Business and Society, 34(2), 197-198.

Wood, D.J. and Jones, R.E. (1995) 'Stakeholder mismatching: A theoretical problem in empirical re- search on corporate social performance', International Journal of Organizational Analysis, 3, 229-267.

Wright, P. and Ferris, S. (1997) 'Agency conflict and corporate strategy: The effect of divestment on corporate value', Strategic Management Journal, 18, 77-83.

Wright, P., Ferris, S.P., Hiller, J.S. and Kroll, M. (1995) 'Competitiveness through management of diversity: Effects on stock price valuation', Academy of Management Journal, 38, 272-287.

Zyglidopoulos, S.C. (2003) 'The issue life-cycle: Implications for reputation for social performance and organizational legitimacy', Corporate Reputation Review, 6(1), 70-81. 